\title{
Evaluating the Economic Performance of Reverse Polymerization Technology for Waste Tyre Recycling in Sub-Saharan Africa
}

\author{
Olatayo KI* \\ Department of Mechanical and Nuclear Engineering, North West University, South Africa
}

${ }^{*}$ Corresponding author: Olatayo KI, Department of Mechanical and Nuclear Engineering, North West University, Private Bag X6001, Potchefstroom 2520, South Africa, Tel: +27(0)182994023; +27(0)182852397; +27(0)182852450, E-mail: kunlefavour@yahoo.com

Citation: Olatayo KI (2019) Evaluating the Economic Performance of Reverse Polymerization Technology for Waste Tyre Recycling in Sub-Saharan Africa. J Waste Resour Recycl 1(1): 104. doi: 10.15744/27665887.1.104

\section{Received Date: March 25, 2019 Accepted Date: August 27, 2019 Published Date: August 29, 2019}

\begin{abstract}
The unlawful and uncontrolled disposal of waste tyres is greatly disturbing in terms of the environmental concerns and the economic misfortune. In combating this menace, there is growing interest in the application of efficient and environmental-friendly alternatives to the traditional recycling methods for waste tyres. Pyrolysis can be considered as an appropriate non-conventional method for complex materials such as tyres. Several works have been made to improve pyrolysis process towards higher yield and quality of biofuels and greater energy efficiency. This study considers Reverse Polymerization, a microwave-assisted pyrolysis process to extract complete yield and higher quality of valuable products, while avoiding toxic emissions into the environment. The feasibility of such innovative recycling process in Sub-Sahara Africa is essential in order to convince concerned authorities to buy into such advanced technologies with great benefits. The investment analysis and economic performance indicators from the study demonstrated that the operation of such proposed recycling system in the continent is economically feasible. However, the operation of such facility under the present market conditions might highly be challenged by high investment risk as the project is highly capital intensive.

Keywords: Waste-Tyre; Recycling; Economic; Reverse-Polymerisation; Pyrolysis; Feasibility

List of abbreviations: AAR: Average Annual Revenue; AMAT: Advance Molecular Agitation Technology; BR: Butadiene Rubber; CC: Contingency Costs; CSABS: Council of the South African Bureau of Standards; CoCT: City of Cape Town; DCF: Discounted Cash Flow; DEA: Department of Environmental Affairs; EU: European Union; FCI: Fixed Capital Investment; IC: Installation Costs; IRR: Internal Rate of Revenue; ISM: Industrial Scientific and Medical; MPU: Microwave Polymerization Unit; NPV: Net Present Value; NR: Natural Rubber; PCT: Passenger Car Tyres; Phr: Parts Per Hundred; PP: Payback Period; R: Rand; REDISA: Recycling and Economic Development Initiative of South Africa; RP: Reverse Polymerization; RPM: Revolution per Minute; RSA: Republic of South Africa; SATRP: South African Tyre Recycling Process; SATMC: South African Tyre Manufacturing Conference; SAWTR: South African Waste Tyre Regulations; SBR: Styrene-Butadiene Rubber; SU: Shredding Unit; TCI: Total Capital Investment; TEC: Total Equipment Costs; TT: Truck Tyres; UK: United Kingdom; US: United States; VAT: Value Added Tax; WC: Working Capital; ZAR: South Africa Rand
\end{abstract}

\section{Introduction}

South Africa generates about 11 million waste tyres [1,2] out of the approximately 1.5 billion that are produced globally every year $[1,3]$. These waste tyres are discarded in dumps and stockpiles in the residential, industrial, townships, and rural areas across the country. The uncontrolled disposal and accumulation of tyres has the potential for extremely dangerous large fires [4]. Also, while many of them are burned for their scrap metal content, and heat generation in the townships and rural areas, particularly during winter, these practices discharge toxic gases such as dioxins and carbon monoxide into the environment. These environmental concerns and the economic misfortune in disposing the valuable resource inherent in tyres following their useful lifetime are driving the country to redefine its waste tyre management practice and institute legal guidelines. The main purpose of these regulations is to cultivate environmentally safe disposal and recover value from waste tyres through recycling.

The Recycling and Economic Development Initiative of South Africa (REDISA) was established by the Department of Environmental Affairs with the primary purpose to regulate the cultivation of environmentally safe disposal and recovery of value from waste tyres through recycling. Through the Integrated Industry Waste Tyre Management Plan, introduced by REDISA, waste tyres can now be recycled into useful products instead of polluting the environment, and as well a potential business opportunity that can contribute to the economic growth of the country. This integrated waste management plan became effective in July 2012 and aligns with the legislated Waste Tyre Regulations of 2009 under the National Environmental Management Act of 2008 [5]. Under this initiative, manufacturers 
and importers of tyres in the country are expected monthly to declare tyres manufactured and imported by weight to REDISA and pay levies. The fee collected is meant to subsidize the collection and transportation of waste tyres, establish a network of waste tyre depots, and support recyclers. This waste tyre management fee charged on new tyres was projected to generate approximately R700 million annually, with $80 \%$ of it being ploughed back into the development of a sustainable waste tyre recycling industry [6].

Due to composition, tyres are problematic waste products to recycle and process. Vulcanized rubber, used in tyres, is a nonbiodegradable and very stable thermo-set compound that cannot be remolded by heating unlike thermoplastics [7] making tyres difficult to dispose or recycle. Automotive tyres consist mostly of a thermoset rubber compound reinforced with steel wires and textile fibers [8]. The specific composition of a tyre will depend on a number of factors including but not limited to: the tyre manufacturer, the vehicle category (passenger car, trucks, van and light utility vehicles, airplanes, etc.), and the weather conditions [9]. All tyres, however, contain the same groups of materials [10,11] in varying design percentages, rubber being the main component. Natural rubber (NR) and styrene-butadiene rubber (SBR) are the most commonly used rubbers for the manufacture of automotive tyres [8]. The markets and applications for recycled waste tyre have developed tremendously over the years [4,12]. Waste tyres have a high content of volatile matters as well as fixed carbon that makes them an interesting solid as a fuel for energy production or hydrogenation processes and generation of different fractions of solid, liquid and gaseous products [2]. Modern attempts to recover value from waste tyres through recycling include size reduction, devulcanisation, and pyrolysis [13]. Pyrolysis can be considered as a suitable non-conventional, efficient, and environmental-friendly method for recycling complex materials such as waste tyres, and different studies have been carried out to improve pyrolysis process towards higher yield and quality of bio-fuels [12].

Reverse polymerization, which is microwave-assisted pyrolysis, is the reduction of organic material through the application of microwave energy in an oxygen depleted (nitrogen-rich) atmosphere [14,15]. The process involves the direct application of highenergy microwaves to organic waste to break down the materials into simpler chemical components. Microwave energy is used to excite and break molecular bonds. This energy is absorbed by the organic material, causing rotation of inter-molecular bonds, leading to the generation and emission of narrow band infrared energy [16]. The narrow band infrared energy is re-absorbed by surrounding material, increasing the amount of energy in the bonds until the bonds break. The breaking of the bonds results in the conversion of complex organic compounds into simpler compounds of lower molecular weight without undergoing oxidation [15]. This technology is neither incineration nor traditional pyrolysis, as both cannot be precisely controlled in the same manner as reverse polymerization.

Microwave-assisted pyrolysis, initially developed by Tech-En Ltd in Hainault, UK [15] is an emerging and one of the most promising heating technologies for pyrolysis, due to its ability to heat quickly and directly any microwave absorbing material [16]. Among polymeric composites, tyres are extremely complex items [17]. Polymers do not have the ability to absorb microwave and turn them into heat however, it is possible to pyrolyse them if they are mixed with a microwave absorbing material $[14,18]$.

Microwaves are electromagnetic waves that range in frequencies from $300 \mathrm{MHz}$ to $300 \mathrm{GHz}$ [9]. The equipment comprises three major components: the source, the transmission line and the applicator [9]. Microwave heating is achieved primarily at either 915 $\mathrm{MHz}(896 \mathrm{MHz}$ in the UK) or $2450 \mathrm{MHz}[19,20]$. The heating is achieved from the interaction of the electric field component of the electromagnetic wave with charged particles in the material via two mechanisms; the dipolar polarization mechanism and the conduction mechanism [9]. Energy is delivered directly through interaction with the electromagnetic field, which results in volumetric heating - unlike conventional heating where the energy is transferred through convection, conduction and radiation [21]. In conventional pyrolysis the heat is transferred via conduction, thus the exterior of the sample is hotter than the interior [9]. In microwave heating, the centre is probably heated first, the exterior acting as an insulator. Volatile gases will pass through low temperature regions and undesired secondary reactions are reduced, producing a cleaner structure [22]. The potential advantages of microwaves are numerous and include [23]: (i) efficient heating, (ii) rapid reaction times, (iii) energy savings, (iv) selective heating and material property dependence that ensures no energy is lost in bulk heating, and (vi) potentially better quality outputs. The use of microwave radiation as a heat source offers an improved uniformity of heat distribution, excellent heat transfer, and provides better control over the heating process. Microwave-driven pyrolysis has been identified as an energy-efficient alternative to the current heating technologies employed for the treatment of problematic waste such as used tyres [24]. A study conducted by [25] proved the feasibility of tyre microwave pyrolysis.

Microwave-assisted pyrolysis of waste tyres has the capability of producing three fractional products: solid (char), liquid (oil), and gas $\left(\mathrm{H}_{2}, \mathrm{CO}, \mathrm{C}_{2} \mathrm{H}_{2}, \mathrm{CH}_{4}, \mathrm{C}_{2} \mathrm{H}_{4}, \mathrm{C}_{2} \mathrm{H}_{6}\right.$, etc.) in varying proportions depending mainly on the temperature [16]. The concentrations and characteristics of each fraction can vary considerably according to the feed characteristics and the operating conditions of the pyrolysis process. The three fractions have the potential to be refined further to produce energy and valuable products such as transportation fuels, hydrogen for oil refining, consumer products, substitute natural gas, fertilizers, chemicals, steams, and electricity.

In support of the REDISA position and plan that the waste tyre industry is in need of funding mechanisms and innovative technologies to rectify the end-of-life waste tyre issue, this study carried out the technical and economic feasibility of an industrialscale waste tyre reverse polymerization plant in Sub-Sahara Africa (using South Africa as a case study) so as to influence the decisions of concerned authorities to consider the application of superior technologies in the promotion of efficient and sustainable treatment of waste tyres in Africa. 


\section{Research Methodology}

The methodology applied for this study is described in this section. The study prospects for a plant that would operate at a proposed recycling rate of about 120 tons of tyres per day, producing several liters of oil and kilograms of carbon black and steel monthly. The applied technology and process design are restricted to available data and not projections. Data relating to different costs and corresponding certifications of the recycling technologies were collated from several literature references and related stakeholders in waste recycling industry in South Africa and beyond. The analyses involved both qualitative and quantitative approach.

\section{Data Collection}

This process involved both the broad review of related literature and interviews with industry professionals. Firstly, existing and available data were collected largely through document reviews (energy journals, legislative acts, doctoral theses, academic publications, policy documents, etc.), and afterwards, new data were generated through primary research, which involved qualitative expert interviews. Purposive sampling was used for the selection of the interviewees as this ensured that the most appropriate stakeholders were consulted. The mode of interview was largely face-to-face, supported by telephone and email correspondence.

\section{Technologies for the Recycling Plant}

The proposed reverse polymerization plant involves the application of two major technologies in two phases. The first phase of technology application will involve the installation of a shredder to reduce the size of the waste tyres. The second phase entails installing microwave reverse polymiser to process the tyre shreds into oil, carbon black, and steel. The down-selection process of the two major technologies, from a list of varied technologies, resulted in the selection of the E4000T Modular Shredding System and EWS Model TR-1500 Microwave Polymerization System for shredding and reverse polymerization of the waste tyres respectively.

The selection of the appropriate technology for the waste tyre reverse polymerization project involved the assessment of a number of entrepreneurial groups and technology providers that have developed (or attempted to develop) shredding and reverse polymerization technologies. Afterward, the technology options are reviewed and screened in accordance with three criteria. First, the technology under consideration should be commercially ready and available and preferably with high technology development. High technology development increases the likelihood that a configuration will perform at the scale defined in this study. Second, the capacity size of the technology plant should be able to accommodate the proposed 120 tons of waste tyres per day. Third, the desired products should be of high quality and compatible to the approved standard by the regulatory authority.

E4000T Modular Shredding System: The E4000T Modular Tyre Shredding System consists of the Inlet Conveyor, Super Chopper SC1412T, Hydraulic Unit, Service Platform, and Vibrating Discharge Conveyor (EDLAN, 2010). The Super Chopper is a powerful, low speed, single or double shaft pre-chopper designed to process whole passenger car and truck tyres (normal maximum diameter of $1200 \mathrm{~mm}$ and maximum width of $450 \mathrm{~mm}$ ) down to shreds. The output from the Super Chopper will be up to approximately 150-300 mm shreds [26]. The system manufactured by EDLAN Recycling A/S Denmark and licensed in South Africa by MMH Recycling Systems, is flexible to process different input materials and produce different output fractions.

EWS Model TR-1500 Microwave Polymerization System: The selected EWS Model TR-1500 system for the reverse polymerization of the waste tyres contains major equipment/components, including the Tyre Feed (loading), Dry Feed Tower (oxygen flushing/ nitrogen purging), Microwave Reduction Chambers (reduction process), Hydrocarbon Reduction Chamber, Power Generation Chamber, Carbon Recovery Chamber, and Scrap Steel Recovery Chamber (EWI, 2012). The TR- 1500 model has the capacity to process 1500 tyres per day, and a total 500,000 tyres annually. The EWS Reverse Polymerization technology and process, when applied to scrap tyres, reduces them to their base components namely carbon black, steel, hydrocarbon gases, and oil. The process recycles $100 \%$ of the scrap tyre feed. Scrap tyres enter the processing area and proceed up an inclined tyre feed into the dry-feed tower.

\section{Investment Costs for Recycling Facilities}

The estimation of the investment costs for the tyre recycling plant involved the determination of the total capital investment and operating costs for the plant. The operating costs comprise of the fixed and variable operating costs.

Capital Investment Estimations: The total capital investment (TCI) for the waste tyre recycling and processing plant is a function of all equipment costs, installation costs, contingency costs, and working capital [2,27]. The total equipment costs (TEC) and installation costs (IC) are determined, and the contingency costs (CC) and working capital (WC) are applied thereafter. The addition of the contingency cost to the total equipment and installation costs gives the fixed capital investment (FCI). The sum of the FCI and working capital (WC) gives the total capital investment for the recycling plant project. Thus, total capital investment, representing the overall investment, is expressed as:

$$
T C I=T E C+I C+C C+W C
$$

Where TEC is the sum of all major and minor equipment costs, $I C$ accounts for direct costs relating to the erection of the equipment and other indirect expenses such as piping, electrical, engineering, construction, and legal fees for a tyre recycling plant. The CC 
is a percentage of the sum of the TEC and IC. The costs of major equipment included the purchase of the tyre shredding plant and microwave polymerization plant, while minor equipment included the purchase of forklift equipment. Data regarding equipment costs and specifications were obtained from technology providers, recycling facilities, related stakeholders, and literature references.

The major cost economic assumptions considered for the capital investment costs analysis are:

1. The total installation cost is estimated at $30 \%$ of TEC [28]

2. The Contingency Costs is estimated at $10 \%$ of (TEC + IC) [28]

3. The Fixed Capital Investment is addition of TEC, IC, and CC [28]

4. The Working Capital is estimated as $15 \%$ of FCI [27]

5. The Total Capital Investment is the addition of FCI and WC [27]

Fixed Operating Cost Estimations: The fixed operating costs considered for the plant include labor, overhead and maintenance of equipment, and insurance and taxes. The Pay Scale index [29] was used to estimate the annual labor costs, assuming three shifts per day. Each shift was assumed to include one microwave polymiser operator, one forklift driver, and two laborers. In addition to the shift workers, one plant manager, and one office clerk was included in the labor costing. Table 1 showed the major assumptions considered for the analysis of the fixed operating costs of the recycling plant. The rent of the industrial project site for the recycling and processing plant is excluded.

\begin{tabular}{|c|c|c|}
\hline Parameter & Estimated Value & Source \\
\hline \multirow{5}{*}{ Labour } & 1 Plant Manager & \\
& $\begin{array}{c}\text { 1 Maintenance Technician } \\
\text { 1 Office Clerk } \\
1 \text { Shredder Operator }(\times 3 \text { Shifts }) \\
\text { 1 Microwave Polymiser Operator }(\times 3 \text { Shifts }) \\
1 \text { Truck \& Front Loader }(\times 3 \text { Shifts }) \\
\text { 2 Labourer }(\times 3 \text { Shifts })\end{array}$ & \\
\hline Maintenance & 11\% of Major Equipment Cost & Levy \& Carley, 1989 \\
\hline Taxes/Insurance & 2\% of Major Equipment Cost & Aden et al. 2002 \\
\hline
\end{tabular}

Table 1: Economic assumptions for fixed operating costs

Variable Operating Cost Estimations: The variable operating costs were calculated as the sum of the electrical power consumption and raw material costs. The only raw material for the reverse polymerization process was the waste tyre shreds, which is free. The variable costs assumptions considered for the economic model of the recycling and processing plant are presented below:

1. The feedstock (waste tyre) is free.

2. The electricity is estimated at R1.64/KWh [30]

3. Transportation of waste tyres to site is by REDISA for free

\section{Economic Performance Models}

The economic performance of the plant was evaluated as it allows an investor to measure the total expenditure and the plant's payback period [31]. Basic economic models for evaluating techno-economic feasibility of investment projects were used, including: Payback Period (PP); Net Present Value (NPV); and Internal Rate of Revenue (IRR) [32], in order to provide a balanced representation. The major economic assumptions considered for the analysis of the economic feasibility of the recycling and processing plant are presented in Table 2 .

\begin{tabular}{|c|c|c|}
\hline Parameter & Estimated Value & Source \\
\hline Financing & $100 \%$ Equity & \\
\hline Discount Rate & $10 \%$ & Swanson et al. 2010 \\
\hline Internal Rate of Return & $10 \%$ & Towler \& Sinnott, 2013 \\
\hline Plant Lifetime Period & 20 years & Edwards, 2016 \\
\hline Plant Availability & $\begin{array}{c}310 \text { days per } \\
\text { year (85\%) }\end{array}$ & Edwards, 2016 \\
\hline
\end{tabular}

Table 2: Main economic assumptions for feasibility of the plant

The payback period (PP) for the recycling facilities is the time period (generally in years) in which a return is required from the investment or the amount of time it takes for the positive cash flow to exceed the initial investment, without concern for the time value of money $[33,34]$. The calculation for PP is expressed as $[32,35]$ :

$$
P P(\text { years })=\text { Investment Cost }(R) / \text { Average Annual Revenue }(R)
$$

Where Investment Cost is all costs for implementation, including capital equipment costs, operating costs, training, installation, etc., and the Average Annual Revenue is the product of the selling price per ton of product and the average annual production output. 
The Net Present Value (NPV) for the recycling facilities operates on a concept of present value and calculates the difference between the present values of cash inflows and the present values of cash outflows, at a given target rate of return or cost of capital [33,35]. A project is financially viable if the NPV is positive, while a negative value signifies an investment that is not viable [33]. The NPV of a uniform cash flow is expressed as $[35,36]$ :

$$
N P V=A A R\left[\frac{(1+i)^{n}-1}{i(1+i)^{n}}\right]-\operatorname{Inv} C
$$

Where AAR is the Average Annual Revenue, $\mathrm{i}$ is the discount rate, $n$ is the lifetime of the plant, and InvC is the Investment Cost.

The Internal Rate of Return (IRR) for the recycling facilities is defined as the discount rate that makes the net present value of the cash flows (both positive and negative) equal to zero [32] The IRR for an investment project is expressed as:

$$
N P V=A A R\left[\frac{(1+i)^{n}-1}{i(1+i)^{n}}\right]-\operatorname{Inv} C=0
$$

The calculation practically is performed iteratively by varying the discount rate.

The TR-1500 Reverse Polymerization process reduces tyres to base components including carbon black, hydrocarbon gases, oil, and steel, yielding almost $100 \%$ reuse and recycling of the waste tyre feed. The followings are the economic assumptions for the recovered products:

1. The TR-1500 plant is designed to process 1,500 tyres $(\approx 150$ tons) per day;

2. The processing will generate an estimated 4.125 tonnes of carbon black (EWI, 2012);

3. An estimated 1.35 tonnes of steel (EWI, 2012);

4. Microwave pyrolysis of a used tyre produces an estimated 125.02 gallons of oil $[15,16]$;

5. The discount rate considered for this study is $10 \%$ [2].

\section{Sensitivity Analysis}

There are some parameters (fixed capital costs, variable costs, selling price of recycled products, rate of production, etc.) that mainly influence the outcome of the economic analysis of waste tyre recycling [2]. The sensitivity of the reverse polymerization plant was carried out by varying the primary economic parameters (around their base case values) that can influence the economic performance of the system.

\section{Results and Discussion}

The study determined important parameters for the recycling facilities such as the estimated investment costs, payback period, net present value, internal rate of return, and life cycle estimation.

\section{Investment Costs}

The estimation of the investment costs involved the determination of the total capital investment and operating costs. The investment costs for both the E4000T Modular Tyre Shredding Unit and EWS Model TR-1500 Microwave polymerization Unit were calculated separately.

Shredding Unit: The capital investment for the shredding unit is presented in Table 3. The estimated total capital investment for the shredding unit of the plant is $\mathrm{R} 17,228,933$. The price for the tyre shredding system includes all shipping, clearing, custom, and VAT charges. The fixed operating cost is shown in Table 4. The annual labor costs were estimated using the PayScale 2015 [29]. The annual labor incurred the largest percentage of the cost at R 1,520,000. The rent of the industrial project site for the recycling and processing plant is excluded. The total fixed operating cost for this phase is $\mathrm{R} 2,881,971$.

\begin{tabular}{|c|c|c|}
\hline Parameter & Estimated Value & Source \\
\hline $\begin{array}{c}\text { Major equipment: E4000T } \\
\text { Tyre Shredding System }\end{array}$ & $8,622,900$ & Quotation \\
\hline $\begin{array}{c}\text { Minor equipment: } \\
\text { Tipper Truck }\end{array}$ & 520,000 & “ \\
Front Loader & 820,800 & \\
Weighbridge & 513,000 & \\
\hline Installation Costs & $3,143,010$ & \\
\hline Contingency Costs & $1,361,971$ & \\
\hline Fixed Capital Investment & $14,981,681$ & \\
\hline Working Capital & $2,247,252$ & \\
\hline Total Capital Investment & $17,228,933$ & \\
\hline
\end{tabular}




\begin{tabular}{|c|c|}
\hline Parameter & Estimated Value \\
\hline Labour 1 Plant Manager & 500,000 \\
1 Office Clerk & 60,000 \\
1 Maintenance Technician & 60,000 \\
1 Shredder Operator/Shift $(\times 3$ Shifts $)$ & 480,000 (@ 160,000 per operator) \\
1 Truck/Loader Driver/Shift (× 3 Shifts) & 180,000 (@ 60,000 per driver) \\
2 Labourers/Shift (× 3 Shifts) & 240,000 (@ 40,000 per labourer) \\
\hline Maintenance & $1,152,437$ \\
\hline Taxes/Insurance & 209,534 \\
\hline Total Fixed Operating Cost & $2,881,971$ \\
\hline
\end{tabular}

Table 4: Estimated fixed operating costs for the shredding phase (ZAR)

The variable operating cost is presented below:

1. The feedstock (waste tyre) is free.

2. The electricity is estimated at $\mathrm{R} 1,771,200$

The variable operating costs contain the costs of electrical power consumption and raw material. The only raw material is the freely supplied scrap tyre. The annual variable operating cost for the shredding phase is R 1,771,200.

Reverse Polymerization Unit: The capital investment for this phase is presented in Table 5. The total capital investment for this phase is R 164,450,000. The minor equipment was previously accounted for in the shredding unit. The fixed operating costs are shown in Table 6 . The total fixed operating cost for microwave polymerization unit is $\mathrm{R} 13,480,000$.

\begin{tabular}{|c|c|}
\hline Parameter & Estimated Value \\
\hline $\begin{array}{c}\text { Major equipment: EWS } \\
\text { Model TR-1500 system }\end{array}$ & $100,000,000$ \\
\hline Installation Costs & $30,000,000$ \\
\hline Contingency Costs & $13,000,000$ \\
\hline Fixed Capital Investment & $143,000,000$ \\
\hline Working Capital & $21,450,000$ \\
\hline Total Capital Investment & $164,450,000$ \\
\hline
\end{tabular}

Table 5: Estimated capital investment costs for the reverse polymerization phase (ZAR)

\begin{tabular}{|c|c|}
\hline Parameter & Estimated Value \\
\hline $\begin{array}{c}\text { Labour 1 Lab Technician } \\
\text { 1 Shredder Operator/Shift }(\times 3 \text { Shifts }) \\
\text { 2 Labourers/Shift }(\times 3 \text { Shifts })\end{array}$ & $\begin{array}{c}60,000 \\
180,000 \text { (@ 60,000 per driver) } \\
240,000 \text { (@ 40,000 per labourer) }\end{array}$ \\
\hline Maintenance & $11,000,000$ \\
\hline Taxes/Insurance & $2,000,000$ \\
\hline Total Fixed Operating Cost & $13,480,000$ \\
\hline
\end{tabular}

Table 6: Estimated fixed operating costs for the reverse polymerization phase (ZAR)

The variable operating cost is presented below:

1. The feedstock (waste tyre) is free.

2. The electricity is estimated at $\mathrm{R} 8,114,064$.

The electricity usage is estimated at $133 \mathrm{kWh}$ per tons of tyre [37]. The total variable operating cost for the reverse polymerization phase is $\mathrm{R} 8,114,064$. The feedstock is free.

Combined Units: The total capital investment, total fixed operating cost, and total variable operating costs for both shredding and reverse polymerization phases of the waste tyre recycling facilities are $\mathrm{R} 181,678,933$, R 16,361,971, and R 9,885,264 respectively, and they are presented in Table 7.

\begin{tabular}{|c|c|c|c|}
\hline Parameter & Shredding & Microwave Polymerisation & Combined \\
\hline Total Capital Investment & $17,228,933$ & $164,450,000$ & $181,678,933$ \\
\hline Fixed Operating Costs & $2,881,971$ & $13,480,000$ & $16,361,971$ \\
\hline Variable Operating Costs & $1,771,200$ & $8,114,064$ & $9,885,264$ \\
\hline Investment Cost & & & $207,926,168$ \\
\hline
\end{tabular}

Table 7: Estimated investment costs for the combined units of the tyre recycling plant (ZAR) 


\section{Economic Feasibility}

The study calculated the primary economic indicators for the recycling facilities, which include Payback Period, Net Present Value, and Internal Rate of Revenue, in order to determine the economic feasibility of the project. With regards to the production assumptions for the derived products in section 2.4, and a projected production of 120 tons per day, the mass fraction of the derived products from the processed waste tyres becomes: 1,023 tons/year of carbon black; 4,650,744 gallons/year of oil; and 334.8 tons/year of steel.

In determining the economic feasibility, the estimated revenues for the products were calculated as the product of the selling price per ton of the derived products and the annual production output. The unit price assumptions for carbon black, oil, and steel are $\$$ 800/tons, \$ 0.594/gallon, and \$35/tons respectively (UC Riverside, 2016). Estimating the processing of 120 tons per day, the total annual incomes for each product are R 10,909,272 for carbon black; R 36,787,385 for oil; and R 156,200 for steel. The total annual revenue for all the products is $\mathrm{R} 47,852,857$. These are presented in Table 8 . The study assumes the net annual cash inflow is same throughout the project lifetime.

\begin{tabular}{|c|c|c|c|}
\hline Product & $\begin{array}{c}\text { Quantity } \\
\text { (Ton/yr) }\end{array}$ & $\begin{array}{c}\text { Unit Price } \\
\text { (ZAR) }\end{array}$ & $\begin{array}{c}\text { Total } \\
\text { Amount }\end{array}$ \\
\hline Carbon Black & 1,023 tons/year & 10,664 & $10,909,272$ \\
\hline Oil & $4,650,744$ gallons/year & 7.91 & $36,787,385$ \\
\hline Steel & 334.8 tons/year & 466.55 & 156,200 \\
\hline Total & & & $47,852,857$ \\
\hline \multicolumn{3}{|c|}{ Table 8: Estimated total revenue per year } \\
\hline
\end{tabular}

Furthermore, applying Equations 2, 3, and 4 to the economic assumptions for the economic feasibility of plant in Table 2, the payback period, net present value and internal rate of return for the project were calculated. The estimated PP for the tyre recycling plant is about 5 years (4.3 years plus additional 1 year allowed for plant installation). Similarly, the plant has a NPV value of R $225,714,128$ and the IRR is estimated at $12 \%$. These results are presented in Table 9.

\begin{tabular}{|c|c|}
\hline Parameter & Estimated Value \\
\hline Payback Period & 5 years \\
\hline Net Present Value & R $225,714,128$ \\
\hline Internal Rate of Return & $12 \%$ \\
\hline
\end{tabular}

Table 9: Economic performance of the tyre recycling plant

\section{Sensitivity Analysis}

The variation of such economic parameters like capital costs, variable costs, selling price of derived products, and production rate will affect the economic feasibility of a project. This study conducted a sensitivity analysis for the recycling plant by varying the Investment Costs and Annual Average Revenue parameters, around its base case values, against the Payback Period and Internal Rate of Revenue for the plant. The base case values for the Investment Costs, Annual Average Revenue, Payback Period and Internal Rate of Revenue are R 207,926,168; R 47,852,857; 5 years; and 12\% respectively, as shown in Table 10. These sensitivities are illustrated in Figures 1,2,3 and 4. An additional 1 year was added to the PP estimates in the sensitivity analysis to allow for plant installation.

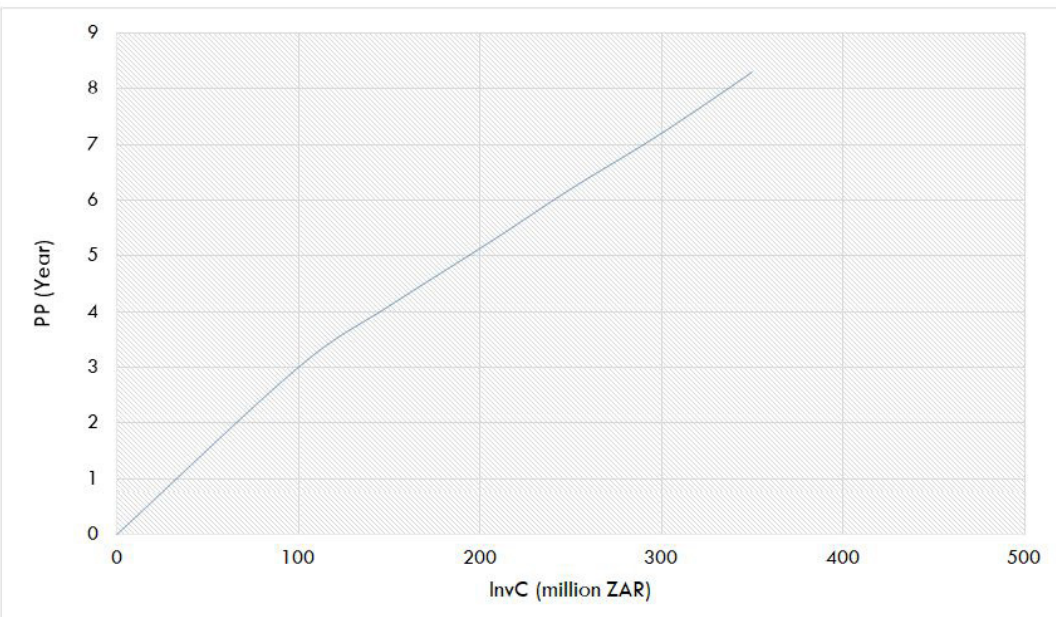

Figure 1: Sensitivity of payback period to investment cost variations for the recycling facilities 


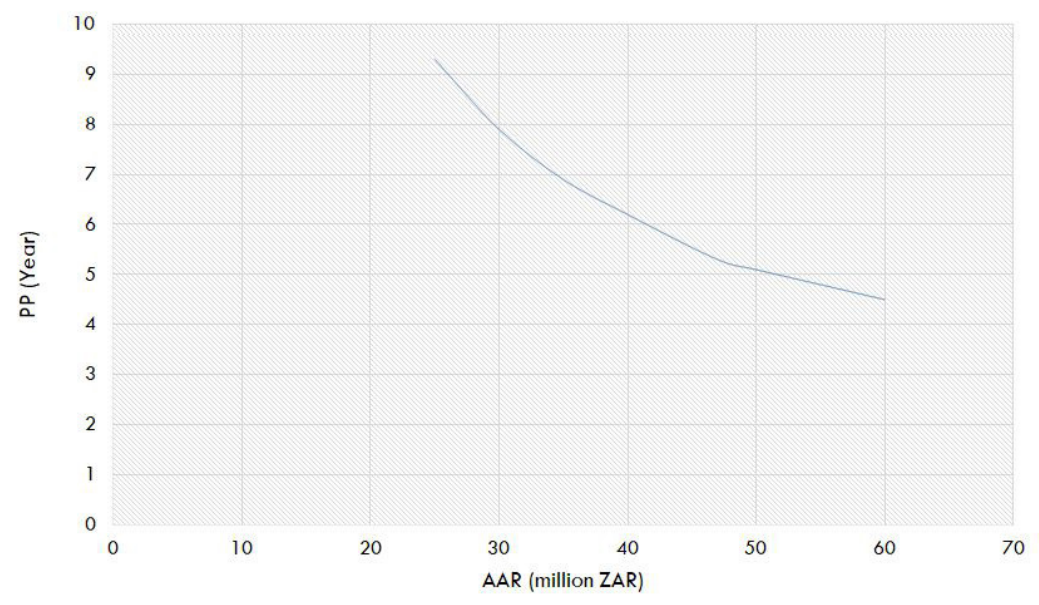

Figure 2: Sensitivity of payback period to average annual revenue variations for the recycling facilities

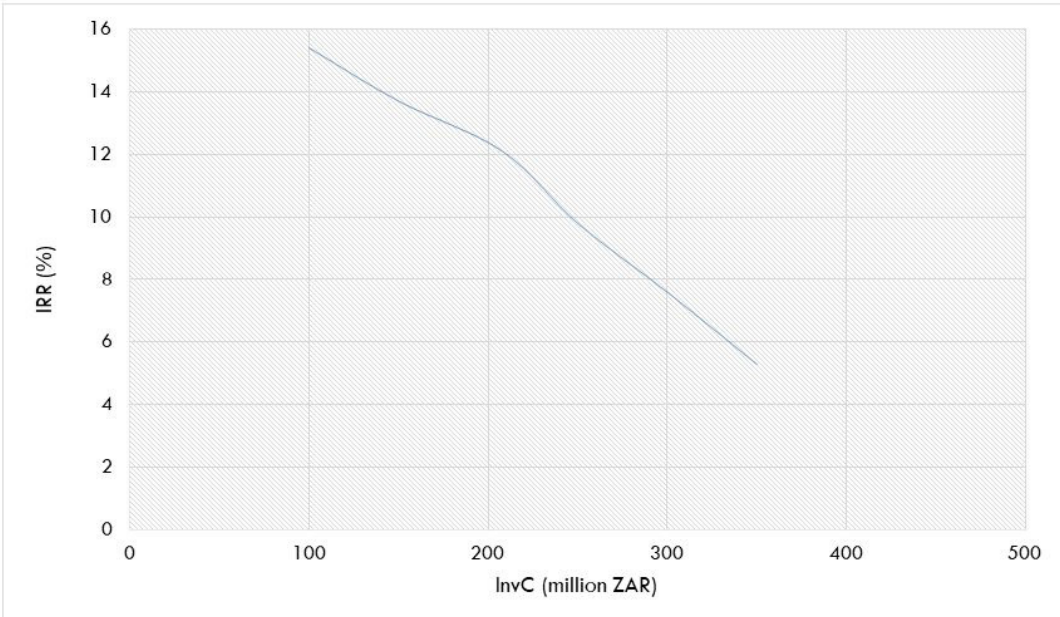

Figure 3: Sensitivity of IRR to investment cost variations for the recycling facilities

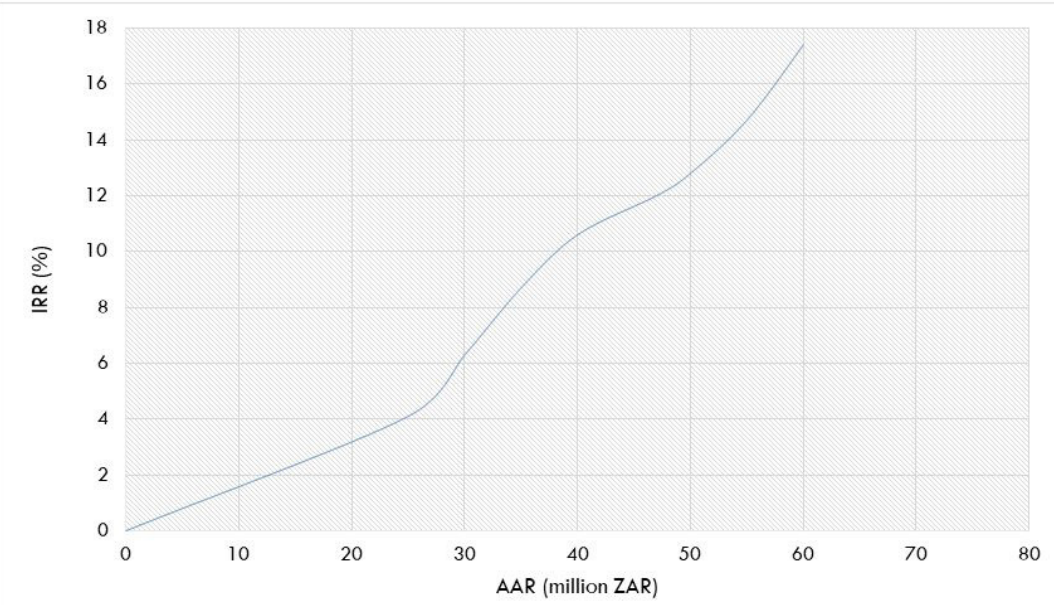

Figure 4: Sensitivity of IRR to average annual revenue variations for the recycling facilities

\begin{tabular}{|c|c|}
\hline Index & Base case value \\
\hline Investment Cost & R $207,926,168$ \\
\hline Annual Average Revenue & R $47,852,857$ \\
\hline Payback Period & 5 years \\
\hline Internal Rate of Revenue & $12 \%$ \\
\hline
\end{tabular}

Table 10: Base case values of indices for sensitivity analysis 


\section{Environmental Cost}

The costs estimated for the reverse polymerisation process in this study did not take into consideration the environmental cost. However, this factor is imperative, particularly if costs are being compared between conventional technology and high environmental friendly technology like reverse polymerisation. In accounting for the environmental loss when processing by conventional means, an additional cost termed external cost or externality is included in the cost estimation. Environmental costs help to estimate the hidden benefits/damages of production not accounted for in the existing pricing system. The determination of the environmental costs of RP systems allows the environmental benefits to be expressed in economic terms. Hence, future work in this area will focus on reporting the environmental cost of RP process against a conventional process of waste tyre recycling.

\section{Discussion}

The application of available highly sophisticated technology for the processing and treatment of wastes including waste tyres provides a reliable, clean, high quality, cost efficient, and safe solution [32]. Analyzing the results showed the estimated PP for the tyre recycling plant is considerably lower than the assumed plant's useful lifetime of 20 years hence profitable, as initial investment may be recovered before the end of the operating lifetime of the recycling plant. Similarly, the plant has a NPV value that is greater than zero, thus, the proposed plant is economically profitable. Furthermore, the IRR is estimated at $12 \%$, greater than minimum rate of return. An investment is considered acceptable if its IRR is greater than an established minimum acceptable rate of return or cost of capital (discount rate associated with the investment), although the IRR should be substantially greater than the discount rate in order to justify an investment in an unproven field [38]. For the economic analysis carried out in this study, the IRR is higher than the discount rate of $10 \%$.

Also, regarding the sensitivity analysis, the variation of the actual values of these economic parameters does affect the economic performance of the recycling facilities. The resulting deviation of the Payback Period and Internal Rate of Return from their base case values demonstrated the sensitivity of the model to variations in the economic parameters. Investment in the Reverse Polymerization technology could be of high risk going by the high sensitivity of the economic model and process. Identifying the factors that could influence negatively the feasibility of the recycling facilities is quite essential [28].

The reverse polymerization plant is the major area of investment for the project. All the cost parameters for this phase are significantly higher than the shredding phase. This is due to the high technicality of the technology and the high operational temperature, raising considerably the electricity consumption. According to Reschner [4] the path to a sustainable and long term economic success in the recycling industry primarily depends on: sound economic and marketing model for the recycled products; selection of appropriate recycling technology; innovative product development; and a supportive government policy [39-60].

\section{Conclusion}

The planned reverse polymerization plant project can be termed as economically feasible from results of the economic performance indicators (aside that the process configuration is not analyzed for electricity generation). However, determining the potential demand for microwave polymerization products is more difficult, as the existing conventional-pyrolysed products and markets are not well-defined. The recycled products are still seeking an established market in South Africa, after years of supposed development in the country and several researched and demonstrated applications of these products globally. The explanations for this may be economic, difficulty of undertaking long term market development in the recycled rubber business, and the arguable quality of the pyrolysed products. Also, there is no known development program on the application of pyrolysed products and markets in the country. Generally, the tyre recycling sector in the country is currently almost a confined market, with the few participants located in Pretoria and Cape-town. These participating companies are confined suppliers of the recycled products. The existing available market is growing at less than the original pace of the industry however considerable high-side potential exists for the industry in the country. This potential will be available if these businesses can expand the use of tyre pyrolysis into an organized market structure, better process technology and product innovations. Furthermore, improving the economic viability of the waste tyre recycling sector will involve direct government initiatives such as subsidies for recycling centers and the supply chain [61-88].

Although, the provision of subsidies and grants is often instrumental to the implementation of a recycling project, it is ultimately up to the ingenuity of business community to identify waste tyre recycling as a potential business opportunity, design and develop economic and market driven solutions, and be socially responsible by creating direct upstream and downstream employment opportunities and a cleaner Africa [89-92].

\section{Acknowledgement}

Great appreciation goes to the Innovation Support Office of the Faculty of Engineering, North-West University Potchefstroom for funding this study, and most importantly, the director, Mr. Andre Hattingh. Also, the MMH Recycling was very helpful in providing cost data for the recycling equipment. Reference in the study to any specific commercial product, process, or service by trade name, trademark, manufacturer, or otherwise does not necessarily constitute or imply its endorsement or recommendation by the author. 


\section{References}

1. Danon B, van der Gryp P, Schwarz CE, Görgens JF (2015) A Review of Dipentene (dl-limonene) Production from Waste Tire Pyrolysis. J Anal Appl Pyrolysis 112: 1-13.

2. Edwards DW (2016) Comparison of the Technical and Economic Feasibility of Devulcanisation Processes for Recycling Waste Tyres in South Africa. Stellenbosch University, South Africa.

3. Williams PT (2013) Pyrolysis of waste tyres: a review. Waste Management 33: 1714 - 28.

4. Reschner K (2008) Scrap Tire Recycling: A Summary of Prevalent Disposal and Recycling Methods. Berlin, Germany.

5. REDISA (2009) REDISA integrated industry waste tyre management plan. Regulation 9, of the Waste Tyre Regulations published in the Government Gazette No. 31901 of 13, South Africa.

6. Botes A (2012) South African Waste Management Tyre Fee to Generate R700 million per Year to promote Tyre Recycling.

7. Adhikari B, De D, Maiti S (2000) Reclamation and Recycling of Waste Rubber. Progress in Polymer Science 25: 909-48.

8. Rodgers B, Waddell W (2013) Tire Engineering In: The Science and Technology of Rubber, Elsevier.

9. Athanassiades E (2013) Waste Tyre Pyrolysis: Sustainable Recovery and Reuse of a Valuable Resource. PhD Thesis. Department of Civil and Environmental Engineering. Imperial College London, UK.

10. Shulman VL (2004) Tyre Recycling. Rapra Review Reports, Rapra Technology Limited, Shawbury, England.

11. Feraldi R, Cashman S, Huff M, Raahauge L (2013) Comparative LCA of Treatment Options for US Scrap Tires Material Recycling and Tire-Derived Fuel Combustion. Int J Life Cycle Assess 3: 613-25.

12. Suhanya, M, Thirumarimurugan M, Kannadasan T (2013) Recovery of Oil from Waste Tyres Using Pyrolysis Method: A Review. Int J Res Eng Technol 2: 81-90.

13. Myhre M, Saiwari S, Dierkes, W, Noordermeer J (2012) Rubber Recycling: Chemistry, Processing, and Applications. Rubber Chem Technol 85: 408-49.

14. Hussain Z, Khan KM, Hussain H (2010) Microwave-metal Interaction Pyrolysis of Polystyrene. J Anal Appl Pyrolysis 89: 39-43.

15. Thostenson ET, Chou TW (1999) Microwave Processing: Fundamentals and Applications. Composites: Part A: Applied Science and Manufacturing 30: 1055-71. 16. Undri A, Meini S, Rosi L, Frediani M, Frediani P (2013) Microwave Pyrolysis of Polymeric Materials: Waste Tires Treatment and Characterization of the Valueadded Products. J Anal Appl Pyrolysis 103: 149-58.

17. Mark JE, Erman B, Eirich FR (2005) Science and Technology of Rubber, Elsevier Academic Press, USA.

18. Ludlow-Palafox C, Chase HA (2001) Microwave-induced Pyrolysis of Plastic Wastes. Ind Eng Chem Res 40: 4749-56.

19. Meredith RJ (1998) Engineers' Handbook of Industrial Microwave Heating. The Institution of Electrical Engineers, London, UK.

20. Chan TVCT, Reader HC (2000) Understanding Microwave Heating Cavities, Artech House Inc., Norwood, UK.

21. Lam SS, Chase HA (2012) A Review on Waste to Energy Processes Using Microwave Pyrolysis. Energies 5: 4209-32.

22. Miura M, Kaga H, Sakurai A, Kakuchi T, Takahashi K (2004) Rapid Pyrolysis of Wood Block by Microwave Heating. J Anal Appl Pyrol 71: 187-99.

23. Jones DA, Lelyveld TP, Mavrofidis SD, Kingman SW, Miles NJ (2002) Microwave Heating Applications in Environmental Engineering - A Review. Resources, Conservation and Recycling 34: 75-90.

24. Appleton TJ, Colder RI, Kingman SW, Lowndes IS, Read AG (2005) Microwave Technology for Energy-Efficient Processing of Waste. Appl Energy 81: 85-11. 25. EDLAN Recycling A/S Denmark (2010) Modular Tyre Shredder, MMH, South Africa.

26. Pang S (2007) Microwave Pyrolysis of Waste Tyres. Imperial College of Science, Technology and Medicine, University of London, UK.

27. Swanson RM, Satrio JA, Brown RC, Platon A, Hsu DD (2010) Techno-Economic Analysis of Biofuels Production Based on Gasification. Technical Report. National Renewable Energy Laboratory, USA.

28. Towler GP, Sinnott RK (2013) Chemical Engineering Design ( $2^{\text {nd }}$ Edn) In: Principles, Practice, and Economics of Plant and Process Design, Elsevier.

29. PayScale (2015) Salary Survey, South Africa.

30. CoCT (2014) Residential Electricity Tariff. Cape Town Electricity Services, City of Cape Town, South Africa.

31. Gagliano A, Nocera, F, Patania F, Capizzi A (2013) Assessment of Micro-wind Turbines Performance in the Urban Environments: An Aided Methodology through Geographical Information Systems. Int J Energy Environ Eng 4: 43.

32. ElQuliti SAH (2016) Techno-Economical Feasibility Study of Waste to Energy Using Pyrolysis Technology for Jeddah Municipal Solid Waste. Int J Power Eng Energy 7.

33. Ayompe L (2011) Performance and Policy Evaluation of Solar Energy Technologies for Domestic Application in Ireland. Dublin Institute of Technology, Dublin, Ireland.

34. Mostafaeipour A (2013) Economic Evaluation of Small Wind Turbine Utilization in Kerman, Iran. Energy Convers Manage 73: 214-25.

35. De Oliveira WS, Fernandes AJ, Gouveia JJB (2011) Economic Metrics for Wind Energy Projects. Int J Energy Environ 2: 1013-38.

36. Kaltschmitt M, Streicher W, Wiese A (2007) Renewable Energy - Technology, Economics and Environment, Springer.

37. Ducharme C (2010) Technical and Economic Analysis of Plasma-assisted Waste-to-Energy processes. Columbia University, USA.

38. Couper JR (2003) Process Engineering Economics (1 ${ }^{\text {st }}$ Edn) CRC Press, USA.

39. Aden A, Ruth M, Ibsen K, Jechura J, Neeves K, et al. (2002) Lignocellulosic Biomass to Ethanol Process Design and Economics Utilizing Co-current Dilute Acid Prehydrolysis and Enzymatic Hydrolysis for Corn Stover. National Renewable Energy Laboratory, Colorado, USA.

40. Myers SC, Brealey RA, (1998) Principles of Business Finance [Princípios de Finanças Empresariais] (5 ${ }^{\text {th }}$ Edn) McGraw-Hill, Lisbon, Portugal.

41. British Standards Institution (BS ISO) (2008) International Organization for Standardization (ISO) 1382: 2008 Rubber - Vocabulary, BSI, London, UK.

42. Brockington RB (1993) Financial Management (6th Edn) DP Publications Ltd, London, UK.

43. Caddick S, Fitzmaurice R (2009) Microwave Enhanced Synthesis. Tetrahedron 65: 3325-55.

44. CalRecovery Inc. (2004) Evaluation of Waste Tire Devulcanization Technologies. California Environmental Protection Agency, Integrated Waste Management Board, California, USA. 
45. Chang, N (2008) Economic and Policy Instrument Analyses in Support of the Scrap Tire Recycling Program in Taiwan. J Environ Manage 86: 435-50. 46. Coran AY (2013) Vulcanization in the Science and Technology of Rubber. Elsevier 2013: 337-81.

47. Council for South African Bureau of Standards (2005) Standard Specification for the Production of reconditioned tyres. SANS 1550.

48. Dean EB (1995) Parametric Cost Deployment, NASA Langley Research Center, Hampton, VA, United States.

49. Dick JS (2001) Rubber Compounding: Introduction, Definitions, and Available Resources ( $1^{\text {st }}$ Edn) In: Rubber Technology, Compounding and Testing for Performance Cincinnati, Hanser Gardner Publications, Munich, Germany.

50. Dolan PJ, Lampo RG, Dearborn JC (1999) Concepts for Reuse and Recycling of Construction and Demolition Waste. US Army Corps of Engineers Construction Engineering Research Laboratories, Washington, USA.

51. Dominguez A, Menendez JA, Inguanzo M, Bernad PL, Pis JJ (2003) Gas Chromatographic-mass Spectrometric Study of the Oil Fractions produced by Microwave-assisted Pyrolysis of Different Sewage Sludges. J Chromatogr A 1012: 193-206.

52. Dominguez A, Menendez JA, Fernandez Y, Pis JJ, Valente Nabais JM, et al. (2007) Conventional and Microwave Induced Pyrolysis of Coffee Hulls for the Production of Hydrogen Rich Fuel Gas. J Anal Appl Pyrolysis 79: 128-35.

53. Duran X, Lenihan H, O’Regan B (2006) A Model for Assessing the Economic Viability of Construction and Demolition Waste Recycling-the Case of Ireland. Resour Conserv Recycl 46: 302-20.

54. El harfi K, Mokhlisse A, Chanaa MB, Outzourhit A (2000) Pyrolysis of the Moroccan (Tarfaya) Oil Shales under Microwave Irradiation. Fuel 79: 733-42.

55. Environment Agency (2004) Life Cycle Assessment of the Management Options for Waste Tyres. Environment Agency R\&D Report, Environment Agency, Bristol, England.

56. Environmental Waste International (2012) EWS Model TR-1500 system.

57. Fernandez Y, Arenillas A, Diez MA, Pis JJ, Menendez JA (2009) Pyrolysis of Glycerol over Activated Carbons for Syngas Production. J Anal Appl Pyrolysis 84: 145-50.

58. Fernandez Y, Menendez JA (2011) Influence of Feed Characteristics on the Microwave-assisted Pyrolysis used to produce Syngas from Biomass Wastes. J Anal Appl Pyrolysis 91: 316-22.

59. Ferrer G (1997) The Economics of Tire Remanufacturing. Resour Conserv Recycl 19: 221-55.

60. Gude VG, Patil P, Martinez-Guerra E, Deng S, Nirmalakhandan N (2013) Microwave Energy Potential for Biodiesel Production. Sustainable Chem Processes 1: 5 .

61. Holland KM (1995) Apparatus for Waste Pyrolysis. US Patent 53873217.

62. Honkamaki O (2012) Shredding Tires is a Prosperous Business.

63. Isayev AI, Liang T, Lewis TM (2013) Effect of Particle Size on Ultrasonic Devulcanization of Tire Rubber in Twin-Screw Extruder. Rubber Chem Technol 87: 86-102.

64. Jang JW, Yoo TS, Oh JS, Iwasaki I (1998) Discarded Tyre Recycling Practices in the United States, Japan and Korea. Resour Conserv Recycl 22: 1-14.

65. Kaplan S (1983) Energy Economics: Quantitative Methods for Energy and Environmental Decisions. McGraw-Hill, New York, USA.

66. Laboy-Nieves EN (2014) Energy Recovery from Scrap Tires: A Sustainable Option for Small Islands like Puerto Rico. Sustainability 6: 3105-21.

67. Laresgoiti MF, de Marco I, Torres A, Caballero B, Cabrero MA, et al. (2000) Chromatographic Analysis of the Gases obtained in Tyre Pyrolysis. J Anal Appl Pyrolysis 55: 43-54.

68. Levy S, Carley JF (1989) Plastics Extrusion Technology Handbook (2nd Edn) Industrial Press, USA.

69. Manar E, Abdul R, Nermine E, Azim A (2010) Thermo-chemical Recycling of Mixture of Scrap Tires and Waste Lubricating Oil into High Caloric Value Products. Energy Convers Manage 51: 1304-10.

70. Menendez JA, Domınguez A, Inguanzo M, Pis JJ (2004) Microwave Pyrolysis of Sewage Sludge: Analysis of the Gas Fraction. J Anal Appl Pyrolysis 7: 657-67.

71. Michelin (2009) What is a tyre? Michelin Motor Tyres.

72. Monsef-Mirzai P, Ravindran M, McWhinnie WR, Burchill P (1995) Rapid Microwave Pyrolysis of Coal: Methodology and Examination of the Residual and Volatile Phases. Fuel 74: 20-7.

73. Netwon T (1995) Wheel of Fortunes Spin for Worn-Out Tyres, Independent.

74. Rashford BS, Macsalka N, Geiger M (2013) Renewable Energy Investment Analysis: What's the Payback? University of Wyoming Extension, USA.

75. Raveendran K, Ganesh A, Khilar KC (1995) Influence of Mineral Matter on Biomass Pyrolysis Characteristics. Fuel 74: 1812-22.

76. Republic of South Africa (2008) The National Environmental Waste Management: Act No. 59 of 2008.

77. Roberts B, Strauss CR (2005) Toward Rapid, “Green”, Predictable Microwave-assisted Synthesis. Acc Chemical Resource 38: 653-61.

78. Rouse MW (2005) Manufacturing Practices for the Development of Crumb Rubber Materials from Whole Tyres ( $1^{\text {st }}$ Edn) In: Rubber Recycling, Taylor and Francis Group, Boca Raton, Florida, USA.

79. Scandinavian Biofuel Company (2011) Microwave Assisted Pyrolysis In: Microwave Pyrolysis.

80. Sienkiewicz M, Kucinska-Lipka J, Janik H, Balas A (2012) Progress in Used Tyres Management in the European Union: A Review. Waste Manage 32: $1742-51$. 81. SATMC (2005) South African Tyre Manufacturing Conference Business Plan, Tyre Recycling Plan and the National Waste Management Strategy Implementation. Project Steering Committee, South Africa.

82. SATRP (2008) South African Tyre Recycling Process.

83. South African Waste Tyre Regulations (2009) Government Notice R.149 promulgated in Government Gazette No. 31901 in terms of the Environment Conservation Act (No. 73 of 1989): Waste Tyre Regulations, South Africa.

84. Swart RJ, Raskin P, Robinson J (2004) The Problem of the Future: Sustainability Science and Scenario Analysis. Global Environ Change 14: 137-46.

85. University of California Riverside (2006) Technology Evaluation and Economic Analysis of Waste Tire Pyrolysis, Gasification, and Liquefaction: Contractor's Report to the Board, Sacramento, CA: California Integrated Waste Management Board, c2006, California, USA.

86. Waddell WH, Bhakuni RS, Barbin WW, Sandstrom PH (1990) Pneumatic Tire Compounding. 
87. Weng YC, Chang NB (2001) The Development of Sanitary Landfill in Taiwan and its Cost Structure Analysis. Resource, Conservation and Recycling 33: 181201.

88. Will H, Scholz P, Ondruschka B (2004) Review Microwave-assisted Heterogeneous Gas Phase Catalysis. Chem Eng Technol 27: 113-22.

89. Yatsun A, Konovalov P, Konovalov N (2008) Gaseous Products of Microwave Pyrolysis of Scrap Tires. Solid Fuel Chem 42: 187-91.

90. Yin C (2012) Microwave-assisted Pyrolysis of Biomass for Liquid Biofuels Production. Bio-resource Technol 120: $273-84$.

91. Zhaoa W, Leeftinkb RB, Rotter VS (2010) Evaluation of the Economic Feasibility for the Recycling of Construction and Demolition Waste in China-The Case of Chongqing. Resour Conserv Recycl 54: 377-89.

92. Menendez JA, Dominguez A, Fernandez Y, Pis JJ (2007) Evidence of Self-Gasification during the Microwave-Induced Pyrolysis of Coffee Hulls. Energy Fuels 21: $373-8$.

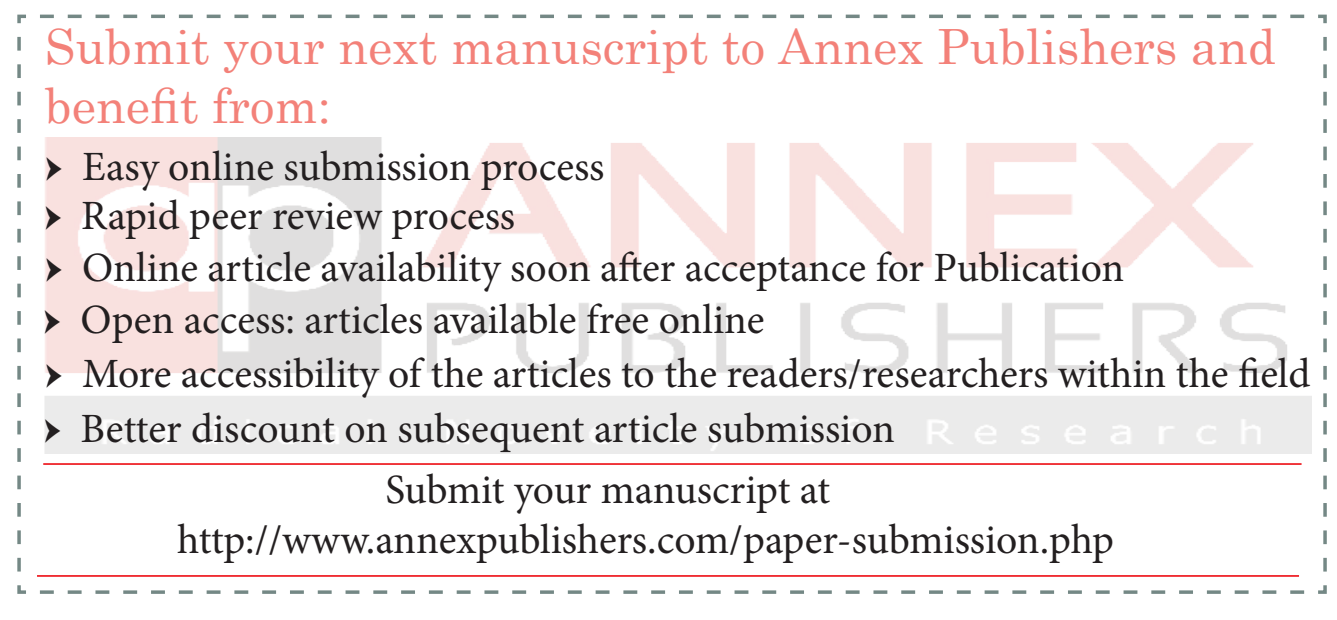

